УДК 005.1: 629.5

JEL M21

DOI 10.31375/2226-1915-2020-4-5-18

ЕКОНОМІЧНЕ СТИМУЛЮВАННЯ В СИСТЕМІ УПРАВЛІННЯ РОЗВИТКОМ ПІДПРИЕМСТВА СУДНОБУДУВАННЯ

\author{
В.Г. Рогов \\ викладач кафедри \\ економіки та організації виробництва \\ Національний університет кораблебудування \\ ім. адм. Макарова, Миколаїв, Украӥна
}

Анотація. Дослідження спрямовано на визначення місия економічного стимулювання в системі управління розвитком підприємств $і$ ролі органів управління підприсмством в економічному стимулюванні.

Обтрунтовано, шео роль органів управління суднобудівним підприємством щодо стимулювання його розвитку полягає у формуванні й використанні стимулів та адаптаиії до ӥхніх змін. Виокремлено адаптацію підприємства до зміни економічних стимулів, щчо полягає в їх ідентифікації та оиіниі за слаб-кими й сильними сигналами, прийнятті рі-шення щзодо доиільності зміни стратегії роз-витку, виборі альтернативної стратегіi або розробиі нової, забезпеченні ії реалізаціі та формуванні нових адаптачійних можливостей. Сформульовано визначення поняття «адаптаиія підприємства до зміни економічних стимулів його розвитку» як безперервний проиес його взаємодії із зовнішнім середовищем та корегування діяльності, активний або пасивний за змістом, шо здійснюеться з метою забезпечення ефективного функиіонування підприсмства. Доведено, ио економічне стимулювання не завжди передбачає вплив ззовні та відносини стимулятора і стимульованого. Розглянуто зарубіжний досвід використання менеджментом суднобудівного підприємства таких стимулів його розвитку як вибір оптимальної спеціалізаиії виробництва та формування морегосподарських кластерів. Наголошено на важливості використання менеджментом стимулів розвитку підприємства як невід'ємної складової його економічного механізму.

Ключові слова: стимулювання, стимули, підприємство, розвиток, управління, адаптачія, інтеграчія.

(C) Рогов В.Г., 2020
УДК 005.1: 629.5

JEL M21

DOI 10.31375/2226-1915-2020-4-5-18

\section{ЭКОНОМИЧЕСКОЕ СТИМУЛИРОВАНИЕ В СИСТЕМЕ УПРАВЛЕНИЯ РАЗВИТИЕМ ПРЕДПРИЯТИЯ СУДОСТРОЕНИЯ}

\section{В. Г. Рогов}

преподаватель кафедрь

экономики и организации производства

Национальный университет кораблестроения им. адм. Макарова, Николаев, Украина

Аннотация. Исследование направлено на определение экономического стимулирования в системе управления развитием предприятий и роли органов управления предприятием в экономическом стимулировании.

Обосновано, что роль органов управления судостроительным предприятием по стимулированию его развития заключается в формировании и использовании стимулов и адаптаиии к их изменениям. Выделена адаптация предприятия к изменению экономических стимулов, которая заключается в их идентификации и оценке по слабым и сильнымм сигналам, принятии решения о иелесообразности изменения стратегии развития, выборе альтернативной стратегии или разработке новой, обеспечении её реализачии и формировании новых адаптационных возможностей. Сформулировано определение понятия «адаптация предприятия к изменению экономических стимулов его развития» как непрерывный проиесс его взаимодействия с внешней средой и корректировки деятельности, активный или пассивный по содержсанию, который осуществляется с иелью обеспечения эффективного функиионирования предприятия. Доказано, что экономическое стимулирование не всегда предполагает воздействие извне и отнотения стимулятора и стимулированного. Рассмотрен зарубежный опыт использования менеджментом судостроительного предприятия таких стимулов его развития как выбор оптимальной спечиализаичи производства и формирования морехозяйственных кластеров. Подчеркнута важность использования менеджментом стимулов развития предприятия как неотъемлемой составляюшей его экономического механизма.

Ключевые слова: стимулирование, стимуль, предприятие, развитие, управление, адаптаичи, интеграция. 
UDC 005.1: 629.5

JEL M21

DOI 10.31375/2226-1915-2020-4-5-18

\title{
ECONOMIC INCENTIVES IN THE SHIPBUILDING DEVELOPMENT MANAGEMENT SYSTEM
}

\author{
Viacheslav Rogov \\ Lecturer of the Department of Business Economics and Production Management \\ orcid id 0000-0002-1847-5907 \\ Viacheslav1988rogov@gmail.com
}

Admiral Makarov National University of Shipbuilding, Mykolaiv, Ukraine

\begin{abstract}
Economic incentives in the post-Soviet professional literature are mostly considered as the state influence on the economy in general or enterprises in particular in order to create motivation for certain actions. The subjectivity of the company's management is admitted only in the material incentives for staff. Incentives are often defined as a set or system of organizational and economic measures and actions.

This approach is partly explained by the fact that incentives are currently considered mainly through the prism of state regulation of enterprises, economic activities, regions and national economy or at the level of productivity increasing, the use of fixed assets, environmental production etc. At the same time, in a market economy, ensuring the shipbuilding enterprise development and the use of effective incentives is primarily the task of its management.

The research is aimed at determining the place of economic incentives in the enterprise development system and the management role in the economic incentives.

It is substantiated that the role of shipbuilding enterprise management in its development stimulation is to form incentives, use them and adapt to their changes. The enterprise adaptation to the economic incentives changes is singled out. It consists in their identification and evaluation by weak and strong signals, decision-making on the expediency of the development strategy changing, choosing an alternative strategy or developing a new one, ensuring its implementation and forming new adaptation opportunities. "The enterprise adaptation to changes in economic incentives for its development» concept is defined as the continuous process of its interaction with the external environment and active or passive adjustment of activities, carried out to ensure the effective functioning of the enterprise. It is proved that economic incentives do not always involve external influence and the relations between the stimulant and the stimulated. The foreign experience of economic incentives using by the shipbuilding enterprise management as the optimum specialization choice and the sea clusters formation is considered. The importance of the use of incentives by the management for enterprise development as an integral part of its economic mechanism is emphasized.
\end{abstract} integration.

Keywords: stimulation, incentives, enterprise, development, management, adaptation,

Постановка проблеми. У пострадянській фаховій літературі залишається погляд на економічне стимулювання як на певний вплив держави на економіку взагалі, та під- приємства зокрема, 3 метою створення мотивації до певних дій i досягнення бажаного для держави результату. Суб'єктність менеджменту підприємства у стимулюванні виз- 
DEVELOPMENT OF MANAGEMENT

AND ENTREPRENEURSHIP METHODS ON TRANSPORT, № 4 (73), 2020
РОЗВИТОК МЕТОДІВ

УПРАВЛІННЯ ТА ГОСПОДАРЮВАННЯ

НА ТРАНСПОРТІ, № 4 (73), 2020 нається тільки стосовно матеріального стимулювання персоналу. При цьому стимули часто визначаються як сукупність або система організаційноекономічних заходів і дій.

Такий підхід певною мірою пояснюється тим, що питання стимулювання наразі розглядаються здебільшого або через призму державного регулювання розвитку підприємств, видів економічної діяльності, регіонів, національної економіки, або на рівні питань підвищення продуктивності праці, використання основних засобів, екологічності виробництва тощо. Водночас в умовах ринкової економіки, забезпечення розвитку суднобудівного підприємства і використання задля цього дієвих стимулів залишається передусім задачею його менеджменту.

Вибір і реалізація оптимальної стратегіï розвитку підприємства в умовах невизначеності зовнішнього i внутрішнього середовища $\epsilon$ першорядним завданням управління підприємством, де роль менеджменту підприємства полягає у формуванні та використанні факторів зовнішнього та внутрішнього середовища як важелів реалізації стратегії розвитку. Це виводить суб'єктність менеджменту підприємства (CEO) у стимулюванні за межі суто матеріального стимулювання персоналу, які досі $€$ характерними для пострадянської фахової літератури. Разом $з$ тим, вона відповідає сучасним поглядам на економічне стимулювання як на процес, що виникає в результаті дії не лише зовнішніх, але i внутрішніх чинників.

Огляд останніх досліджень та публікацій. Питанням стимулів в економіці приділяється значна увага 3 боку вітчизняних та зарубіжних науковців, серед яких Г.В. Сфімова [1], С.В. Мочерний [2; 3], О.С. Літвінов [4], Дж.-Дж. Лаффонт, Д. Мартимор [5], Д. Крисцинські, Р. Кофф, Б. Кемпбелл [6], М. Чаудей [7], Дж. Джоу, С. Лі, Б. Ванг [8], Дж. Ï, X. Ванг, Г.Й. Лі [9] тощо. Водночас поки що відсутнє єдине розуміння економічного стимулювання розвитку підприємства. Т.В. Куклінова розрізняє зовнішне та внутрішне стимулювання розвитку підприємств [10]. До зовнішнього вона відносить фінансовокредитне, нормативно-правове та організаційне стимулювання (розвиток інфраструктури), а до внутрішнього впровадження інновацій, адаптацію організаційної структури та формування інтелектуального капіталу. Звідси логічно випливає, що суб'єктом внутрішнього стимулювання $\epsilon$ органи управління підприємством. 3 таким твердженням важко не погодитися. Проте запропонований зміст внутрішнього стимулювання залишає місце для подальших досліджень форм участі органів управління суднобудівним підприємством у стимулюванні його розвитку.

Мета дослідження. Метою дослідження $\epsilon$ викладення авторського бачення щодо ролі менеджменту суднобудівного підприємства у формуванні й використанні стимулів його розвитку та адаптації до їхніх змін.

Основний матеріал дослідження. Розуміння економічних стимулів як факторів зовнішнього i внутрішнього середовища підприємства, що системно впливають на його розвиток і мають застосовуватися в якості важелів реалізації кор- 
DEVELOPMENT OF MANAGEMENT

AND ENTREPRENEURSHIP METHODS ON TRANSPORT, № 4 (73), 2020
РОЗВИТОК МЕТОДІВ

УПРАВЛІННЯ ТА ГОСПОДАРЮВАННЯ

НА ТРАНСПОРТІ, № 4 (73), 2020 поративних стратегій, передусім об’єктивно призводить до висновку щодо необхідності застосування механізму адаптації до зміни цих факторів. Від ефективності механізму залежить не лише сила, але й вектор впливу стимулів на розвиток підприємства, адже будь-яка зміна умов господарювання надає шанси для розвитку i створює певні загрози. За відсутності своєчасної адаптації, навіть до таких позитивних для бізнесу змін як зменшення податкових i кредитних ставок, економічні показники підприємства можуть погіршитися, якщо його конкуренти повною мірою скористаються новими можливостями власного розвитку.

Адаптація до зміни стимулів розвитку підприємства має включати такі складові:

- ідентифікація та оцінка стимулів за слабкими й сильними сигналами;

- прийняття рішення щодо доцільності зміни стратегії розвитку підприємства;

- вибір альтернативної стратегії або розробка нової;

- забезпечення реалізації стратегії розвитку підприємства.

Таким чином, адаптація до зміни економічних стимулів розвитку підприємства являє собою безперервний, циклічний процес. Така адаптація також може бути пасивною і активною. Наприклад, активна адаптація до збільшення облікової ставки НБУ та відповідно ставок за банківськими кредитами передбачає запровадження комплексу заходів щодо підвищення класу кредитоспроможності підприємства, що мають на меті зменшення очікуваної вартості його позикового капіталу. Пасивна адаптація на зазначену зміну економічних стимулів зводиться до згортання програм, що фінансуються за рахунок банківських кредитів і коригування структури капіталу. В разі очікуваного запровадження в Україні системи торгівлі квотами на викиди парникових газів, підприємства матимуть альтернативний вибір між впровадженням заходів 3 екологічної модернізації виробництва (активна адаптація) та вирішенням питань щодо фінансування закупівлі додаткових квот (пасивна адаптація).

Зрозуміло, що активна адаптація, на відміну від пасивної, спроможна забезпечити істотний економічний ефект у стратегічній перспективі. Проте підприємство далеко не завжди реагує на зміну стимулів діями, спрямованими на зміну вектору впливу зовнішнього середовища на його розвиток. Це обумовлюється не тільки, і не стільки, вадами сис-теми менеджменту, скільки неможли-вістю акумулювати ресурси у достат-ньому обсязі за прийнятною вартістю капіталу та економічною неефективністю заходів активної адаптації за існуючих зовнішніх і внутрішніх умов.

3 викладеного вище випливає, що адаптація підприємства до зміни економічних стимулів його розвитку - це безперервний процес його взаємодії із зовнішнім середовищем та корегування діяльності, активний або пасивний за змістом, що здійснюється 3 метою забезпечення ефективного функціонування підприємства. Результатом адаптації підприємства, як відкритої системи, до зміни стимулів його розвитку $\epsilon$ послідовний перехід системи у нові рівноважні 
DEVELOPMENT OF MANAGEMENT

AND ENTREPRENEURSHIP METHODS ON TRANSPORT, № 4 (73), 2020
РОЗВИТОК МЕТОДІВ

УПРАВЛІННЯ ТА ГОСПОДАРЮВАННЯ

НА ТРАНСПОРТІ, № 4 (73), 2020 стани відповідні новим умовам діяльності.

Роль органів управління суднобудівним підприємством в економічному стимулюванні його розвитку не обмежується адаптацією до зміни стимулів. Підприємства мають можливості перетворювати фактори зовнішнього та внутрішнього середовища на важелі реалізації стратегії розвитку, тобто формувати нові економічні стимули. 3 огляду на специфіку суднобудування, це передусім стосується вертикальної та горизонтальної інтеграції, морегосподарських кластерів і спеціалізації підприємств.

Значний вплив на розвиток підприємства мають такі економічні стимули як форми суспільного розподілу праці та його організації: спеціалізація, концентрація, кооперація та інтеграція. Вони створюються та використовуються менеджментом підприємства 3 метою забезпечення його розвитку. Тому економічне стимулювання не завжди передбачає вплив ззовні та відносини стимулятора і стимульованого.

Інтеграція підприємств суднобудування може також відбуватися шляхом формування морегосподарських або суднобудівних кластерів, що сприяють швидшому впровадженню наукових розробок та інновацій у виробництво, а також підвищенню кваліфікації працівників. Про доцільність застосування кластерного підходу свідчить досвід розвинутих морських держав: Південної Кореї, Японії, Італії, Німеччини, Франції, Фінляндії, Норвегії тощо.

Водночас для української морської індустрії наразі характерним $\epsilon$ вкрай низький рівень взаємодії між основними суб'єктами: власниками вантажів, судновласниками, портами, суднобудівними та судноремонтними підприємствами, науковими інститутами i проектними організаціями. Отже, суднобудівним підприємствам України доцільно використовувати світовий досвід формування та функціонування морегосподарських кластерів як економічний стимул упровадження сучасних технологій, реалізації інноваційних проектів та підвищення конкурентоспроможності продукції.

Практика свідчить, що дієвим стимулом розвитку суднобудівного підприємства може стати рішення органів його управління щодо вибору оптимальної спеціалізації виробництва. Наприклад, передумовою конкурентних переваг підприємств суднобудування Європейського Союзу на світовому ринку $є$ їхнє фокусування на будівництві високотехнологічних інноваційних суден. У результаті європейські суднобудівники хоча й поступаються азійським верфям за кількістю побудованих суден, проте є конкурентоздатними за загальною вартістю побудованого флоту.

Незважаючи на негативні тенденції на світовому ринку суден, спеціалізація підприємств суднобудування Європейського Союзу на створенні складних високотехнологічних суден допомагає їм зберігати та навіть збільшувати кількість контрактів. Так, у 2017 р., хоча сумарний світовий дедвейт замовлень на нові судна скоротився з 152027 до 143694 тис. тонн, європейські суднобудівники змогли наростити портфель замовлень 3 7,347 до 10,289 тис. тонн. У результаті частка Європейського 
DEVELOPMENT OF MANAGEMENT

AND ENTREPRENEURSHIP METHODS ON TRANSPORT, № 4 (73), 2020
РОЗВИТОК МЕТОДІВ

УПРАВЛІННЯ ТА ГОСПОДАРЮВАННЯ

НА ТРАНСПОРТІ, № 4 (73), 2020
Союзу на світовому ринку нових суден у 2017 р. становила приблизно $8 \%$, посідаючи четверте місце у світі після Китаю, Південної Кореї та Японії [11].

3-поміж стимулів розвитку, які формуються за ініціативою, організаційною і фінансовою участю суднобудівних підприємств, слід зазначити також спеціалізовані інститути інвестиційного та кредитного ринків (інвестиційні та експортні кредитні агентства, посередницькі фірми i фонди). Так у 2012 р. в Японії здебільшого за рахунок внесків суднобудівних підприємств було створено Товариство сприяння інвестицій у суднобудування - JSIF. За схемою роботи JSIF, судна, побудовані в Японії, здаються в довгострокову оренду 3 правом викупу в кінці строку. Пріоритет надається екологічним суднам.

Для будівництва судна верф звертається до JSIF 3 клопотанням про створення за кордоном компанії спеціального призначення, яка придбаває судно. Компанія спеціального призначення одержує до 80 \% фінансування від Японського банку міжнародного співробітництва та інших фінансових установ, а залишок вкладає верф, що отримує замовлення, та в разі необхідності - ii інші партнери. Побудоване судно здається іноземній судноплавній компанії на умовах довгострокового бербоут-чартеру та продається їй в кінці терміну дії договору. Отримані таким чином кошти дають змогу суднобудівному підприємству сплатити залишок за кредитом та повернути вкладений власний капітал [12].

У Німеччині впродовж приб- лизно 40 останніх років суднобудівні підприємства 3 метою залучення капіталу для будівництва суден користуються послугами KG-компаній у формі командитних товариств через фондів-посередників - товариств 3 обмеженою відповідальністю. Кожен фонд, як правило, здійснює залучення капіталу на фінансування будівництва лише одного судна. Ці фонди-посередники акумулюють кошти приватних інвесторів, які зі свого боку мають можливість отримати податкову знижку [13, с. 15].

Слід зазначити також вагому участь менеджменту підприємства у формуванні стимулів державного регулювання. Зазвичай вплив суднобудівних підприємств на законотворчу діяльність відбувається через Асоціацію суднобудівників України «Укрсудпром». Завдяки колективним зусиллям суднобудівних підприємств-членів Асоціації свого часу у Податковому кодексі було передбачено галузеве застосування податкових векселів і прийнято Закон України 5209-VI «Про проведення економічного експерименту щодо державної підтримки суднобудівної промисловості» [14].

Сьогодні в центрі уваги членів асоціації, в площині формування економічних стимулів розвитку, є забезпечення приведення міністерствами та іншими центральними органами виконавчої влади їх нормативноправових актів у відповідність із зазначеним Законом, моніторинг та контроль за проведенням експерименту, внесення правок у законопроект № 1182-1-д «Про внутрішній водний транспорт» 3 метою удосконалення регулювання суднобудуван- 
DEVELOPMENT OF MANAGEMENT

AND ENTREPRENEURSHIP METHODS ON TRANSPORT, № 4 (73), 2020
РОЗВИТОК МЕТОДІВ

УПРАВЛІННЯ ТА ГОСПОДАРЮВАННЯ

НА ТРАНСПОРТІ, № 4 (73), 2020 ня та судноплавання [15], а також ініціація діяльності Експортно-кредитного агентства.

Окрім участі у формуванні зовнішніх стимулів розвитку, менеджмент підприємства розробляє матеріальні (грошові i негрошові) та моральні стимули ефективної праці персоналу. Як справедливо зазначають А. Климчук і А. Михайлов «розвиток підприємства відбувається за умов розвитку персоналу, який $\epsilon$ вмотивованим до досягнення мети, що стоїть перед підприємством, i потреби якого задоволені шляхом застосування відповідних форм і методів стимулювання» [16]. Проте, слід підкреслити, що стимулювання персоналу не $є$ тотожнім стимулюванню розвитку підприємства, а також не є його складовою.

Стимули трудової діяльності $\epsilon$ важелями впливу на працівників. Економічні стимули розвитку є важелями системного впливу на підприємство як суб'єкт господарювання. Їх формування i використання спрямоване на створення і реалізацію стратегій розвитку підприємства, що відповідають державним, суспільним i корпоративним інтересам. Стимулювання персоналу має на меті створення та/або посилення мотивації працівників у досягненні визначених стратегічних і тактичних цілей структурних підрозділів і підприємства в цілому. Отже, методи стимулювання персоналу, такі як надбавки до заробітної платні, преміювання, зокрема конвертованими облігаціями і варантами, соціальні пакети, підвищення кваліфікації, кар'єрне зростання тощо, $з$ одного боку залежать від економічних стимулів і обумовлених їх застосуванням стратегічних цілей, а 3 іншого боку, є умовою дієвості економічного стимулювання.

Нарешті, важливе місце у системі функціонального менеджмен-ту посідає використання стимулів розвитку підприємства як невід'ємної складової його економічного механізму. Так, ставки за кредитами, компенсаційний механізм кредитних агентств та інвестиційні преференції застосовуються для оптимізації струк тури капіталу в процесі розробки стратегії його залучення. Варто зазначити, що ці стимули належать до інструментарію вартісно-орієнтованого менеджменту.

Податкові стимули також використовуються СЕО як важелі стратегічного управління, спрямованого на максимізацію вартості підприємства та забезпечення його збалансованого розвитку. Зокрема, ставки екологічного податку, єдиного соціального внеску та методи прискореного нарахування амортизації істотно впливають на мотивацію осіб, що приймають рішення щодо впровадження енергоефективних «зелених» технологій. Разом 3 тим, зниження ефективності податкових стимулів, наприклад, проблеми 3 відшкодуванням ПДВ експортерам, збіднює інструментарій менеджменту, що призводить до реалізації схем оптимізації оподаткування, які не сприяють гармонізації корпоративних і суспільних інтересів.

Широкою є сфера застосування підприємством стимулів вертикальної i горизонтальної інтеграції. Керівництво підприємств, що входять до складу холдингової групи, використовують фактор вертикальної інтеграції для отримання конкурентних 
DEVELOPMENT OF MANAGEMENT

AND ENTREPRENEURSHIP METHODS ON TRANSPORT, № 4 (73), 2020
РОЗВИТОК МЕТОДІВ

УПРАВЛІННЯ ТА ГОСПОДАРЮВАННЯ

НА ТРАНСПОРТІ, № 4 (73), 2020 переваг від перерозподілу ресурсів i побудови ланцюжків постачань (виробництва продукції та перевезень морським i річковим транспортом). Яскравим прикладом результатів використання цього виду стимулів $\epsilon$ розвиток суднобудівно-судноремонтного заводу «Нібулон» у складі холдингової групи, яка об'єднує також виробників сільськогосподарської продукції та суднохідну компанію.

Ефект застосування економічних стимулів взагалі та горизонтальної інтеграції зокрема залежить від професіоналізму керівництва підприємства. 3 огляду на сучасну практику використання можливостей, які надають суднобудівним підприємствам об'єднання в асоціації та інші форми горизонтальної інтеграції можна констатувати наявність істотного нерозкритого потенціалу зростання за рахунок імплементації результатів спільних досліджень ринків капіталу та збуту, а також координації зусиль щодо формування інституційного середовища, сприятливого для розвитку вітчизняного суднобудування. Не в меншій мірі це стосується і використання потенціалу створення морегосподарських кластерів. Види економічних стимулів розвитку суднобудівного підприємства та роль його менеджменту у стимулюванні узагальнено на рис. 1.

Викладене вище уможливлює визначення місця економічного стимулювання в системі управління розвитком підприємства суднобудування. Необхідною передумовою будьякого управлінського процесу $є$ його інформаційно-аналітичне забезпечення. Для управління розвитком підприємства як відкритої системи робота 3 інформаційними потоками, що надходять із зовнішнього і внутрішнього середовища, набуває особливо важливого значення. Вона включає визначення виду і обсягів необхідної інформації, іiі збирання, зокрема за слабкими сигналами, обробку, аналіз і використання для вирішення завдань менеджменту та досягнення стратегічних цілей.

Сучасні вимоги до повноти i якості інформаційно-аналітичного забезпечення об'єктивно призвели до створення на підприємствах відповідної підсистеми менеджменту. 3 огляду на те, що економічними стимулами $\epsilon$ фактори системного впливу зовнішнього i внутрішнього середовища через форми економічних відносин, цілком зрозуміло, що функціонування такої підсистеми стає відправною точкою стимулювання розвитку суднобудівного підприємства в системі його управління (рис. 2). 3 іншого боку, у підсистему інформаційно-аналітичного забезпечення мають поступати звітні дані та матеріали аналізу щодо кінцевого результату дії економічних стимулів, тобто налагодженим має бути й зворотній зв' язок.

Прийняття рішення щодо доцільності корегування стратегії розвитку підприємства, або переходу до альтернативної стратегії приймається 3 урахуванням формування нових стимулів і адаптації до їх зміни. Використання стимулів і забезпечення мотивації персоналу підприємства забезпечують успіх вибраної стратегії. Ці процеси потребують реалізації всіх основних функцій менеджменту: прогнозування, визначення цілей, планування, мотивації, контролю, організації та координації. 


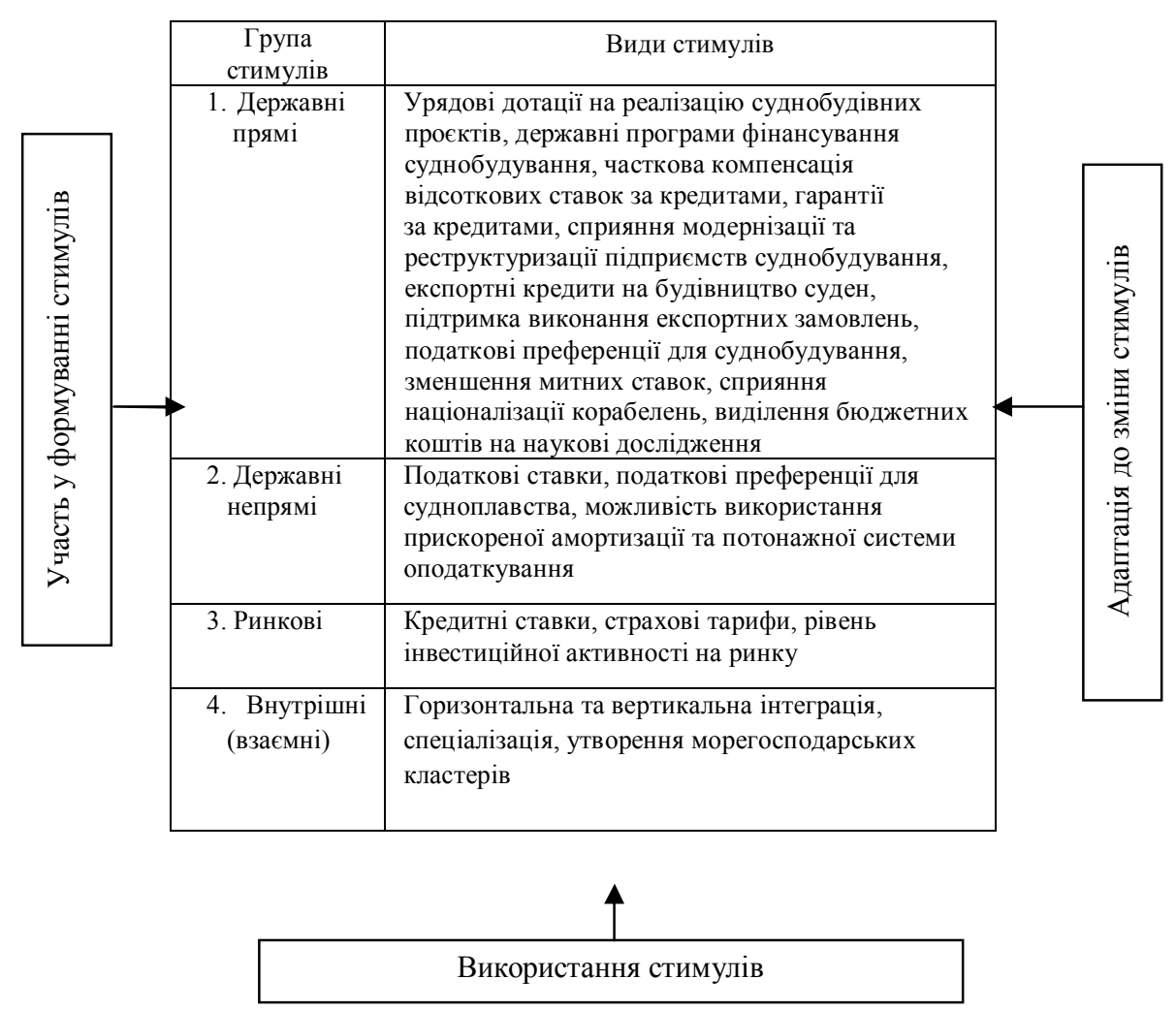

Рис. 1. Роль органів управління суднобудівним підприємством в економічному стимулюванні його розвитку

\section{Джерело: розроблено автором}

Так, функція прогнозування $\epsilon$ базовою у підсистемі інформаційноаналітичного забезпечення. Визначення цілей задає напрямок процесам формування економічних стимулів i адаптації до їх зміни. Ця функція менеджменту лежить також в основі будь яких стратегічних рішень, що приймаються за результатами зазначених процесів. Усі складові еконо- мічного стимулювання (формування i використання стимулів та адаптація до їх зміни) повинні бути об’єктами планування й контролю, а задіяний персонал має бути вмотивованим. Організація та координація залишається центральною функцією управління і в контексті економічного стимулювання розвитку суднобудівного підприємства. 


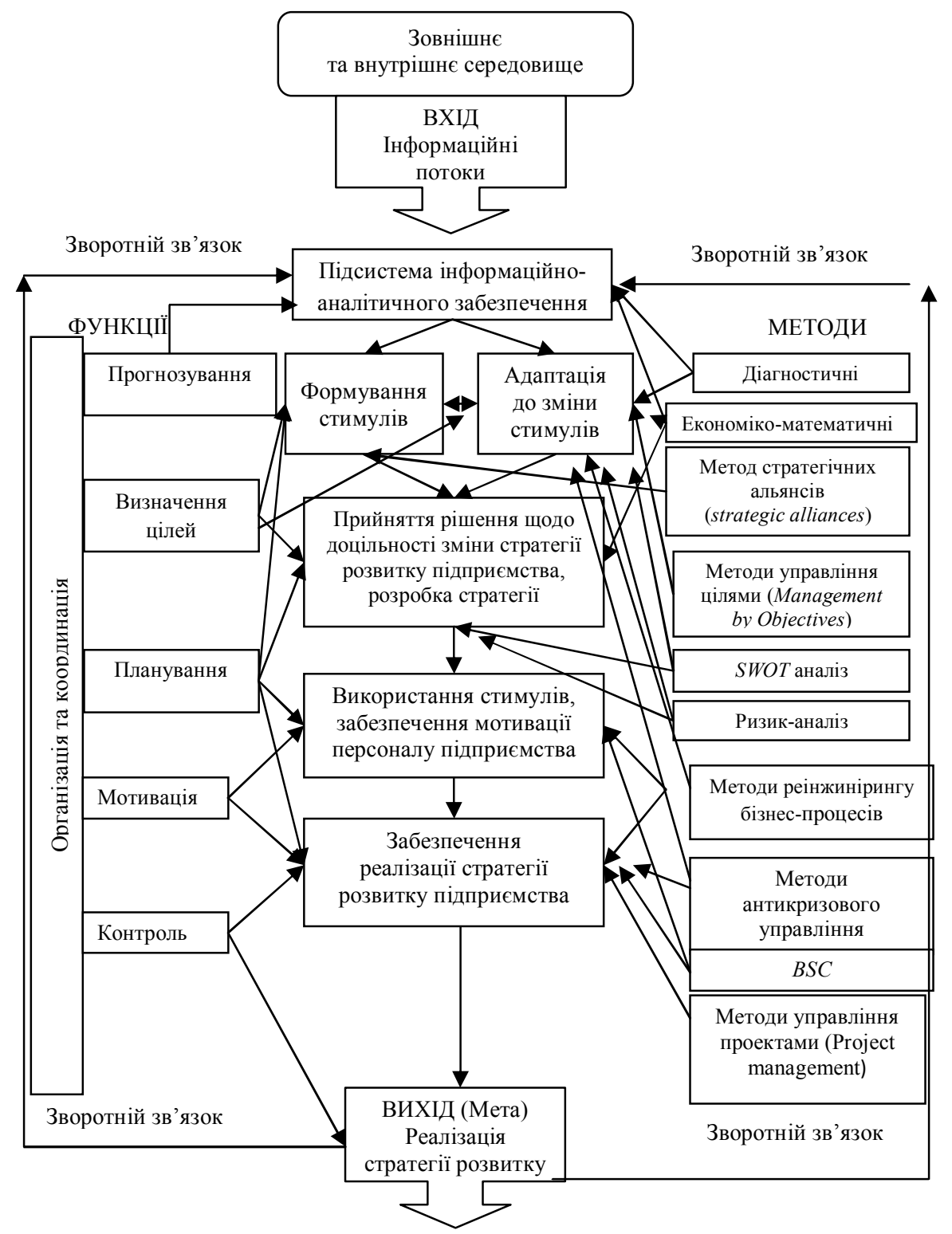

Рис. 2. Стимулювання розвитку суднобудівного підприємства в системі менеджменту

Джерело: розроблено автором

Цілі стимулювання можуть бути досягнуті лише за застосування комплексу методів менеджменту. Зокрема, проведенню якісної адаптації до зміни стимулів сприяє використання $S W O T$ і ризик-аналізу, методів управління цілями, реінжинірингу бізнеспроцесів у поєднанні з рядом діаг- 
DEVELOPMENT OF MANAGEMENT

AND ENTREPRENEURSHIP METHODS ON TRANSPORT, № 4 (73), 2020
РОЗВИТОК МЕТОДІВ

УПРАВЛІННЯ ТА ГОСПОДАРЮВАННЯ

НА ТРАНСПОРТІ, № 4 (73), 2020 ностичних та економіко-математичних методів. У процесі формування стимулів розвитку суднобудівного підприємства, 3 огляду на ефективність горизонтальної і вертикальної інтеграції, чималу перспективу має метод стратегічних альянсів. Зручним і дієвим у використанні економічних стимулів для забезпечення сталого корпоративного розвитку виявляється метод збалансованих показників (BSC). Реалізація функцій менеджменту та обгрунтоване застосування сучасних методів управління в процесі економічного стимулювання $\epsilon$ необхідною умовою досягнення кінцевої мети, а саме забезпечення наміченої траєкторії розвитку суднобудівного підприємства.

Висновки. Роль органів управління суднобудівним підприємством у стимулюванні його розвитку полягає у безпосередньому формуванні внутрішніх (взаємних) економічних стимулів, участі в удосконаленні державних і ринкових стимулів, адаптації до зміни стимулів i їх використанні. Окрім участі у формуванні зовнішніх стимулів розвитку, менеджмент підприємства розробляє матеріальні (грошові і негрошові) та моральні стимули ефективної праці персоналу.

3 огляду на специфіку суднобудування, можливості підприємств перетворювати фактори зовнішнього та внутрішнього середовища на важелі реалізації стратегії розвитку, тобто формувати нові взаємні економічні стимули стосуються, передусім, вертикальної та горизонтальної інтеграціiі, морегосподарських кластерів і спеціалізації виробництва. Вплив суд- нобудівних підприємств на формування державних стимулів переважно відбувається через Асоціацію суднобудівників України «Укрсудпром».

Адаптація підприємства до зміни економічних стимулів полягає в їх ідентифікації та оцінці за слабкими й сильними сигналами, прийнятті рішення щодо доцільності зміни стратегії розвитку, виборі альтернативної стратегії або розробці нової, забезпеченні іiі реалізації та формуванні нових адаптаційних можливостей (зворотній зв'язок). Адаптація підприємства до зміни економічних стимулів його розвитку - це безперервний процес його взаємодії із зовнішнім середовищем та корегування діяльності, активний або пасивний за змістом, що здійснюється 3 метою забезпечення ефективного функціонування підприємства. Результатом адаптації підприємства, як відкритої системи, до зміни стимулів його розвитку є послідовний перехід системи у нові рівноважні стани відповідні новим умовам діяльності. Важливе місце у системі функціонального менеджменту посідає також використання стимулів розвитку підприємства, як невід'ємної складової його економічного механізму.

Стимулювання розвитку суднобудівного підприємства в системі його управління має здійснюватися 3 використанням підсистеми інформаційно-аналітичного забезпечення, функцій і комплексу методів менеджменту. Це є необхідною умовою досягнення кінцевої мети, а саме забезпечення наміченої траєкторії розвитку суднобудівного підприємства. 


\section{СПИСОК ЛІТЕРАТУРИ}

1. Сфімова Г.В. Реструктуризаиія суднобудівних підприсмств як основа їх економічного зростання [Текст] // Науковий вісник Івано-Франківського національного технічного університету нафти і газу. Серія: Економіка та управління в нафтовій і газовій промисловості. 2015. № 1. C. 127-133. URL: http://nbuv.gov.ua/UJRN/nvifnunge_2015_1_22.

2. Економічна енциклопедія: У трьох томах. T. 1. [Текст] / Редкол.: ... С.В. Мочерний (відп. ред.) та ін. К.: Видавничий иентр «Академія», 2000. 864 c.

3. Економічна енциклопедія: У трьох томах. Т. 3. [Текст] / Редкол.: ... С.В. Мочерний (відп. ред.) та ін. К.: Видавничий иентрр «Академія», 2002. $952 c$.

4. Літвінов О.С. Дискусійні питання сутності стимулів в економіиі [Текст] // Вісник соціально-економічних досліджень. 2009. № 37. С. 105.

5. Laffont, J.-J. (2001) The Theory of Incentives: The Principal-Agent Model / Jean-Jacques Laffont, David Martimort. Princeton University Press. 421 p.

6. Kryscynski, D., Coff, R., Campbell, B. (2020). Charting a path between firmspecific incentives and human capital-based competitive advantage. Strategic Management journal.

7. Chaudey, M. (2017). Why test the theory of incentives in a dynamic framework? SSRN Electronic Journal. 2017. DOI: 10.2139/ssrn.3076882

8. Zhou, J., Li, S., Wang, B. Investigation of dynamic incentive of supply chain under information asymmetry for screening. Mathematical Problems in Engineering, 2019. https://doi.org/10.1155/2019/9547931

9. Yi, J., Wang, H., Li, Y. (2018). Designing efficient and incentive compatible mechanisms is almost impossible in quasi-linear environments. Economics Letters, 173, 113-117.

10. Куклінова Т. В. Внутрішне стимулювання розвитку малих та середніх підприємств [Текст] // Вісник Хмельнищького національного університету. 2011. № 2. T.2. C. 68-72.

11. The Shipbuilders' Association of Japan (2018). Shipbuilding Statistics. URL: https://www.sajn.or.jp/files/view/articles_doc/src/3fe433aa57ab8215782b4a 6bdf2fffaa.pdf.

12. OECD (2016). Peer Review of the Japanese Shipbuilding Industry, OECD Publishing. URL: https://www.oecd.org/japan/PeerReview-ShipbuildingJapan.pdf.

13. Akol, S. (2008). KG Financing Methodology in Maritime Industry: German Evidence. URL: https://shippingfinance.files.wordpress.com/2016/07/2008akol_kg-financing-methodology-in-maritime-industry german-evidence.pdf.

14. Закон України «Про проведення економічного експерименту щодо державної підтримки суднобудівної промисловості» № 5209-VI від 06.09.2012 p. URL: https://zakon.rada.gov.ua/laws/show/5209-17. 
15. Проект Закону Украӥни «Про внутрішній водний транспорт» № 1182-

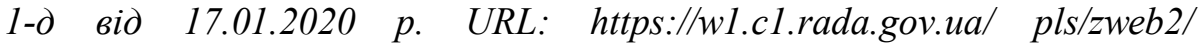
webproc4_1?pf3511=66739.

16. Климчук А.О., Михайлов А.М. Мотивація та стимулювання персоналу в ефективному управлінні підприємством та підвищенні інновачійноі діяльності [Текст] // Маркетинг і менеджмент інновацій. 2018. № 1. C. 218-234.

\section{REFERENCES}

1. Yefimova, H.V. (2015) Restrukturyzatsiia sudnobudivnykh pidpryiemstv iak osnova ikh ekonomichnoho zrostannia [Restructuring of shipbuilding enterprises as the basis of economic development]. Naukovyj visnyk IvanoFrankivs'koho natsional'noho tekhnichnoho universytetu nafty $i$ hazu. Seriia: Ekonomika ta upravlinnia $v$ naftovij $i$ hazovij promyslovosti 1 - Scientific Bulletin of Ivano-Frankivsk National Technical University of Oil and Gas. Series: Economics and Management in the Oil and Gas Industry, 127-133 [in Ukrainian].

2. Mochernyj, S.V. (2000). Ekonomichna entsyklopediia: U tr'okh tomakh. [Economic encyclopedia: In three volumes. Vol. 1. Kyiv: Vydavnychyj tsentr «Akademiia», 864 [in Ukrainian].

3. Mochernyj, S.V. (2002). Ekonomichna entsyklopediia: $U$ tr'okh tomakh. [Economic encyclopedia: In three volumes Vol. 3. Kyiv: Vydavnychyj tsentr «Akademiia», 952 [in Ukrainian].

4. Litvinov, O.S. (2009). Dyskusijni pytannia sutnosti stymuliv v ekonomitsi [Debatable issues of the essence of incentives in the economy]. Visnyk sotsial'no-ekonomichnykh doslidzhen' // Bulletin of socio-economic research. 37, 105 [in Ukrainian].

5. Laffont, J.-J. (2001). The Theory of Incentives: The Principal-Agent Model. Jean-Jacques Laffont, David Martimort. Princeton University Press. 421 p.

6. Kryscynski, D., Coff, R., Campbell, B. (2020). Charting a path between firmspecific incentives and human capital-based competitive advantage. Strategic Management journal.

7. Chaudey, M. (2017). Why test the theory of incentives in a dynamic framework? SSRN Electronic Journal. DOI: 10.2139/ssrn.3076882

8. Zhou, J., Li, S. \& Wang, B. (2019). Investigation of dynamic incentive of supply chain under information asymmetry for screening. Mathematical Problems in Engineering. Retrieved from https://doi.org/10.1155/2019/9547931

9. Yi, J., Wang, H., Li, Y. (2018). Designing efficient and incentive compatible mechanisms is almost impossible in quasi-linear environments. Economics Letters, 173, 113-117. 
10. Kuklinova, T.V. (2011). Vnutrishnie stymuliuvannia rozvytku malykh ta serednikh pidpryiemstv [Internal stimulation of small and medium enterprises development]. Visnyk Khmel'nyts'koho natsional'noho universytetu - Bulletin of Khmelnytsky National University. 2(2), 68-72 [in Ukrainian].

11. The Shipbuilders' Association of Japan (2018) Shipbuilding Statistics. Retrieved from https://www.sajn.or.jp/files/view/articles_doc/src/ 3fe433aa 57 ab8215782b4a6bdf2ffaa.pdf.

12. OECD (2016) Peer Review of the Japanese Shipbuilding Industry, OECD Publishing. Retrieved from https://www.oecd.org/japan/PeerReviewShipbuilding-Japan.pdf.

13. Akol, S. (2008). KG Financing Methodology in Maritime Industry: German Evidence. Retrieved from https://shippingfinance.files.wordpress.com/ 2016/07/2008-akol_kg-financing-methodology-in-maritime-industry_germanevidence.pdf.

14. Zakon Ukrainy "Pro provedennia ekonomichnoho eksperymentu schodo derzhavnoi pidtrymky sudnobudivnoi promyslovosti» [The Law of Ukraine «On conducting an economic experiment on state support of the shipbuilding industry». № 5209-VI from 06.09.2012. Retrieved from: https://zakon. rada.gov.ua/laws/show/5209-17 [in Ukrainian].

15. Proekt Zakonu Ukrainy «Pro vnutrishnij vodnyj transport» [Draft Law of Ukraine «On Inland Water Transport». № 1182-1-d from 17.01.2020. Retrieved from https://w1.c1.rada.gov.ua/pls/zweb2/ webproc4_1?pf3511 $=66739$ [in Ukrainian].

16. Klymchuk, A.O. \& Mykhajlov, A.M. (2018). Motyvatsiia ta stymuliuvannia personalu $v$ efektyvnomu upravlinni pidpryiemstvom ta pidvyschenni innovatsijnoi diial'nosti [The motivation and stimulation of personnel in effective enterprise management and innovation activity improving]. Marketynh $i$ menedzhment innovatsii - Marketing and Management of Innovations, 1, 218-234 [in Ukrainian].

Стаття надійшла до редакиії 16.11.2020

Посилання на статтю: Рогов В.Г. Економічне стимулювання в системі управління розвитком підприємства суднобудування // Розвиток методів управління та господарювання на транспорті: Зб. наук. праць, 2020. № 4 (73). С. 5-18. DOI 10.31375/2226-1915-2020-4-5-18.

Article received 16.11.2020

Reference a JournalArtic: Rogov, Viacheslav. (2020). Economic incentives in the shipbuilding development management system. Development of management and entrepreneurship methods on transport. 4 (73), 5-18. DOI 10.31375/2226-1915-2020-4-5-18. 